\title{
Productivity as an Indicator of Proper use of Human Resource Management of Presbyterian Secondary Schools in Cameroon
}

\author{
Lemnyuy Bongajum Dora \\ PhD Fellow, Educational Foundations and Administration (EFA), \\ Faculty of Education, University of Buea, Buea, Cameroon
}

\begin{abstract}
The study sought to access the degree/level of training and development of workers of Presbyterian secondary schools in the North West, South West and Littoral regions of Cameroon as one of the factors that influence efficiency/effectiveness leading to productivity. As methodology, related literature on the historical and contextual development of formal education in Cameroon which has Presbyterian education authority as a co-provider of education to Cameroonians was reviewed. The two main concepts of training/development and productivity were also reviewed. The survey designed was employed for the study. Data was collected with the use of reports, diaries, written documents, questionnaire, interviews and focused group discussion. A sampled size of 156 made up of teachers, administrators and students of Presbyterian secondary school in Cameroon was used.

The following conclusions were made:

A. Majority of PEA workers are not trained teachers and administrators. They are degree holders in various subjects.

B. If productivity of Presbyterian secondary schools in Cameroon is measured using external examinations, then two major issues arises: GCE ordinary/advanced level in both general and commercial sections are apparently good. Scores are above $90 \%$ averagely for a period of five years. Quantitatively, the results are very efficient. Qualitatively, the results are poor thus qualifying the Presbyterian secondary schools as less effective. Above $60 \%$ scored from $\mathrm{C}$ and $\mathrm{E}$ on both levels.

C. Base on the research question, workers of Presbyterian secondary schools in Cameroon are trained and developed. The level/degree of development in human resource management is just average thereby negatively influencing productivity of Presbyterian secondary schools in Cameroon. The following recommendations were made: Administrators training be included in the ISTP programme and be sent for further training in educational administration at the University of Buea or any other training institution. Secondly, a teaching training institution be open by the Presbyterian Church in Cameroon to train her teachers of the secondary school level.
\end{abstract}

KEYWORDS: Productivity, Human Resource Management, Presbyterian Secondary Schools in Cameroon

\section{INTRODUCTION}

It has been studied and concluded that no organization can be efficient/effective so long as the basic fact remains unrecognized. This basic fact is, was and will always be principally human resource whose efforts/energies lead to effectiveness/efficiency of an establishment. It is not therefore as clearly stated by Faruk, Mustafa, Chowdhury, Farzana, (2014):

\section{A mass of machines and technological processes, but a body of humans. It is not a complex matter, but a complex of humanity. It fulfils its function not by some impersonal force, but by human energy. Its body is not an intricate maze of mechanical devices but a magnified nervous system. All the activities of an enterprise are initiated and determined by persons who make up that institution.}

Human resource management process or administration is, therefore, a very necessary tool in an educational establishment like any other organization for the achievement of greater, effective and efficient productivity. For an educational establishment to achieve its goals, the importance of human resource management process cannot be over-emphasized.

The purpose of human resource management process is to maximize the productivity of an organization by optimizing the effectiveness of employees. The effectiveness of the employees can be optimized through the effective use of the processes of planning, motivation, training, recruitment/selection and appraisal among other variables. It is very imperative for an institution to ensure that the institutional goals and objectives are achieved. Without which, the institution ceases to be effective and efficient thereby negatively influencing productivity.

This study, therefore, seeks to explore the strength of the administrative as well as teaching staff of Presbyterian secondary schools in Cameroon. In principle and practice, the academic and skills acquisition capacity of the administrative and teaching staff is expected to influence the internal/external efficiency/ effectiveness of the Presbyterian secondary school.

Historical Development of Formal Education in
Cameroon
Cameroon is a Central African nation in the Gulf of Guinea.
Bantu speakers were among the first groups to settle in
Cameroon, followed by the Muslim Fulani until German
domination in 1884. After World War I, the French took over
80\% of the area, and the British 20\%. After World War II,
self-government was granted, and in 1972, a unitary republic
was formed out of East and West Cameroon. Until 1976
there were two separate education systems, French and
English, which did not merge seamlessly. The two separate
systems of education still exist despite the government's
effort to harmonize (Tchombe, 2003). The hand writing on


the wall shows that the English sub system of education is undergoing a gradual assimilation process to French Educational sub system. It is worth noting that both systems are 'sub' to no 'main' system; a challenge! This has brought the recent crises in the country and the Anglophone problem in particular in relation to education. English and French are now considered the primary languages of instruction. Local languages are generally not taught. There are too many local languages, and choosing between them would raise further issues (Tambo, 2002, MacOjong, 2008\&Fonkeng 2011). There is usually a day for 'mother tongue' where students are expected to speak and present activities in their various languages.

Formal education in Cameroon in general was introduced by the missionaries in the early 1800 (Mac0jong, 2008). Since then, the Christian mission schools have played a significant role in educating children whose parents can afford to sponsor them. But most parents cannot. Corruption is still a problem and facilities remain basic. Generally, most schools in Cameroon do not have toilets, access to pipe borne water, enough tables and benches for students. Teachers are poorly trained and poorly motivated ("Cameroon Web/EDUCATION IN CAMEROON" Retrieved June 2017). Secondary schools are expensive especially confessional schools in which Presbyterian secondary schools falls in this category.

Generally, absenteeism of teachers is one of the reasons considered to contribute to the poor level of education in the country. This is one of the indicators of poor productivity. For cultural and historical reasons, teachers from both English and French sub-systems still operate as separate in the educational system. This prevents teachers from developing a joint pedagogical repertoire about professional matters and to engage in productive debates around new discourses and repertoires such as ICTs in support of teaching. As private initiatives, private individuals, appear to be open to the challenges of modern Cameroon and multilingual communication in large urban centres (Edith, 2012).

\section{The Presbyterian Educational Authority (PEA)}

As a guiding principle on education in Cameroon in general, Law No 98/004 of 14 April 1998 to lay down guide lines for education in Cameroon Section 2 article 1, 2 and 3 states that education shall be a top priority of the Nation; shall be provided by the state and private sector partner shall assist in providing education in Cameroon. Thus the Presbyterian educational authority (PEA) falls under the law of the nation in providing education. It is owned by the Presbyterian Church in Cameroon. The Presbyterian Church in Cameroon (PCC) is the historical and constitutional successor of the Basel Mission Church in Kamerun, established in 1886 as an external arm of the Evangelical Missionary Society of Basel (Basel Mission) from Switzerland. It maintains the spiritual and theological continuity of that Church, and upholds the Reformed Tradition (PCC Constitution).

The Presbyterian Church in Cameroon has as her mission "to proclaim the good news of God, through Jesus Christ, in word and action. The proclamation of this good news includes the preaching of the Word, teaching, healing and liberating the people of God from sin" (Luke 4:18-19). In this light, the educational sector of the PCC has taken up the responsibility of assisting the government in her teaching ministry to educate the citizens of Cameroon and beyond as one of the
Church's missions stipulates. She engaged in holistic education of the child and has all the levels of education. The name she adopted for the educational sector is "Presbyterian Education Authority (PEA). This name applies to basic and secondary levels of the educational sector of the PCC. Higher education sector is not included.

The Presbyterian Education Authority (PEA) is out to proclaim the Good News of God through Jesus Christ in the teaching ministry of the Presbyterian Church in Cameroon. In this wise; the Presbyterian Education Authority (PEA) has as a sub mission to: Provide devoted, sustainable and affordable high moral, quality Education to all, at all times within available resources. Such education shall be provided wherever and whenever possible and under appropriate conditions in a supplementary and complementary rather than competitive manner, and in compliance with all status governing education in Cameroon. The PEA shall provide particularly education, which is based on the need of the society and shall be provided to the young people of the urban and the rural areas of Cameroon. Lastly, the PEA shall fulfil this Mission with a deep commitment to human dignity and basic human rights, and the moral and ethical obligations of the Education profession (PCC Constitution).

History reveals as recorded by Nku (ed) (1982), (article writer Eugene A. Editi) that in December, 1886, the Basel Mission took over the evangelistic work from the English Baptist Mission. The church at the same time inherited the educational work of that Mission. Education was considered very important by the Basel mission because of the following reasons:-

$>$ Evangelization,

$>$ Production of Christian Workers

$>$ Christian education.

\section{Evangelisation:}

Apart from converting young un-Christian Cameroonian children to Christianity, another very important reason according to Nku (1982) was that every convert should be educated in order to be able to read the word of God as contained in the Bible.

\section{Production of Christian Workers:}

Schools were seen as a sure means of producing catechists, pastors, Christian teachers, Christian clerks, traders, artisans and future leaders of the country. Thus, products from the PEA at that time were consumed by the PCC, society and state. PEA external efficiency started from primary to secondary schools. PCC did not lose sight of the fact that education was principally the task of the government, because of the benefits and importance of education in the society, the church got completely involved in participating in it.

\section{Christian education:}

In November 1957, the Presbyterian Church in Cameroon took over the evangelistic work of the Basel Mission. The Church was also to take over the services of the other arms of the Church such as education, medical and rural developments were to follow at appropriate time. Thus, in November 1966, the Presbyterian Church took over the educational services from the Basel Mission. This was important because the church participates in education as a means to contribute to national development as visible sign of productivity in the early years of church's schools. The 
church was assured of continuous government support of educational work in the form of grants-in-aid, under the system operative when the Basel Mission ran them.

It was not long; it became clear that the responsibility which the Church had inherited was far more demanding than was the case hitherto (Nku (1982). The church is still battling with the PEA up to date to ensure that productivity is achieved.

\section{TRAINING AND DEVELOPMENT}

General concept of training and professional development as an influence to productivity

Training and development is regarded in human resource management as a function concerned with organizational activity aimed at bettering the job performance of individuals and groups in organizational settings. Training and development can be described as an educational process which involves the sharpening of skills, concepts, changing of attitude and gaining more knowledge to enhance the performance of employees. When performances of employees are optimized, productivity is maximized in an educational establishment. Among other things, personal development may include the following activities as stated by Walton (1999):

$>$ Improving self-awareness

$>$ Improving self-knowledge

$>$ Building or renewing identity/self-esteem

$>$ Developing strengths or talents

$>$ Improving career

$>$ Identifying or improving potential

> Building employees ability or (alternatively) human capital

$>$ Enhancing life style and/or the quality of life and timemanagement

$>$ Improving health

$>$ Improving wealth or social status

$>$ Fulfilling aspirations

$>$ Initiating a life enterprise

$>$ Defining and executing personal development plans (PDPs)

$>$ Improving social relations or emotional intelligence

Training and development of worker in an organization is a tool for human capital development. The human capital of an organization consists of the people who work there and on whom the success of the business depends (Ulasi, 2011). Bontis (1999) sees Human capital as representing the human factor in the organization; the combined intelligence, skills and expertise that give the organization its distinctive character. The human elements of the organization are those that are capable of learning, changing, innovating and providing the creative thrust which if properly motivated can ensure the long-term survival of the organization.

More importantly, human capital can be regarded as the prime asset of an organization. Businesses need to invest in that asset to ensure their survival and growth. Human resource management therefore aims at ensuring that the organization obtains and retains the skilled, committed and well-motivated workforce it needs through training and development. This means taking steps to assess and satisfy future needs of the people and to enhance and develop their inherent capacities - their contributions, potential and employability - by providing learning and continuous development opportunities (Ulasi 2011). It involves the operation of 'rigorous recruitment and selection procedures, performance-contingent incentive compensation systems, and management development and training activities linked to the needs of the business' (Becker, Huselid, Pickus, and Spratt, 1997). It also means engaging in talent management the process of acquiring and nurturing talent, wherever it is and wherever it is needed, by using a number of interdependent HRM policies and practices in the fields of resourcing, learning and development, performance management and succession planning. All these are to ensure greater productivity.

Efficiency/effectiveness of an educational organisation can be achieved through Glickman (1985) 'course beyond oneself' developmental strategy. This involves direct assistance to teacher, in-service education and curriculum development. All of these are under the administrator's supervision role. According to Pratzner (1984), every major research on effective schools has noted the organizational phenomenon of collective action, agreed on-purpose and belief in attainment.

Knowledge is one of the prerequisite for an effective and efficient organization. Therefore knowledge management in training and development is mandatory. Knowledge management is a process or practice of creating, acquiring, capturing, sharing and using knowledge, wherever it resides, to enhance learning and performance in organizations (Scarborough, Swan, and Preston, 1999). HRM aims to support the development of organization specific knowledge and skills that are the result of organizational learning processes. This is to ensure the attainment of productivity. For training and development in an organization to be effective, training and development strategies are needed.

Training and Development Strategy

According to Armstrong (2009), training and development strategy represents the approach an organization adopts to ensure the present and future of the organization. Training and development activities support the achievement of its goals by developing the skills and capacities of individuals and teams. It is described similarly by Walton (1999) as strategic human resource management which involves introducing, eliminating, modifying, directing and guiding processes in such a way that all individuals and teams are equipped with the skills, knowledge and competences they require to undertake current and future tasks required by the organization. Training and development encompass three main activities: training, education, and development (Harrison, 2005, Montaria, (2000) and Garavan, Costine, and Heraty, 1995)

Training: This activity is both focused upon, and evaluated against the job that an individual currently holds (Garavan, Costine, and Heraty, 1995).

Education: This activity focuses upon the jobs that an individual may potentially hold in the future, and is evaluated against those jobs

Development: This activity focuses upon the activities that the organization employing the individual, or that the individual is part of, may partake in the future, and is almost impossible to evaluate (Ibid). Before any strategy on training and development can be implemented, trainers are supposed to be identified, trained (or given orientation) before engaging into the process. 
Trainers of Trainees in Training and Development for Effectiveness and Efficiency in an Organization

When training is mentioned, a trainer and trainee are expected to follow. This gives room for the discussion on the stakeholders on training and development. The "stakeholders" in training and development are categorized into several classes. The sponsors of training and development are senior managers. The clients of training and development are business planners in the business context (which fit well in any other organization aimed at business oriented). Line managers are responsible for coaching, resources, and performance. The participants are those who actually undergo the processes. The facilitators are human resource management staff. And the providers are specialists in the field. Each of these groups has its own agenda and motivations, which sometimes conflict with the agendas and motivations of the others (Torington, Hall and Taylow, 2004). These are stakeholders whom without their contributions to training and development, there can never be effective learning and development as influencing factor to effectiveness and efficiency in an organization. It is a collective strategy of merging all that is expected for proper training to take place. This also involves the type of training given to workers in every organization since organizations are united in diversity base on their different objectives.

\section{Types of Training and Development Programs}

Every organization has training and development programs specifically designed to meet up with the organization's goals and objectives. In this light, the following are training and development approaches available for organizations. They are: on-the-job training, mentoring, apprenticeship, simulation (imitation of a process or situation), web-based learning, instructor-led classroom training, action research, programmed self-instruction, case studies/role playing, systematic job rotations and transfers etc (Anthanasias, 2012). All of these are applicable to educational organizations as enhancing factors/strategies for teachers/administrators to develop giving assurance to effectiveness and efficiency as a means to productivity.

Typical roles in the field generally include executive and supervisory/management development, new-employee orientation, professional-skills training, technical/job training, customer-service training, sales-and-marketing training, and health-and-safety training. These learning and development strategies as means to attain productivity help in talent development of employees.

Talent development is the process of changing an organization through its employees, its stakeholders, and groups of people within it, using planned and unplanned learning, in order to achieve and maintain a competitive advantage for the organization. Rothwell notes that those in need of talent development could be a team in search of a meaning; like in management. He went ahead to suggest that 'it be thought of as selective attention paid to the top $10 \%$ of employees, either by potential or performance' (Williams \& Kazanas, 2004, and William 2005). While talent development is reserved for the top management, it is becoming increasingly clear that career development is necessary for the retention of any employee, no matter their level in the company. Research has shown that some type of career path is necessary for job satisfaction and hence job retention (ibid). Personnel development leads to the following benefits to individuals and originations:-increased productivity, less supervision, job satisfaction and skills development.

\section{Contents of the Training and Development Strategy}

Content of what is to be taught in any training and development programme is important and should be relevant. It should be designed in accordance with the organizations' goals and objectives aimed at promoting human capital advantage. It should also be people-led, which means taking into account the needs and aspiration of people to grow and develop. Achieving the latter aim, of course, supports the achievement of the former (Armstrong, 2009). The content should be very relevant to the needs of the organization (educational institution and teacher/or any other involved in development). This will ensure efficiency and effectiveness of employees thereby guaranteeing greater productivity of the organization (educational). For an organization to achieve its objective of training and development of worker for greater productivity, it must have to develop and instil learning culture in its worker; the urge to learn and develop.

Learning Culture as a Factor to Effectiveness/Efficiency Alearning culture is one that promotes learning because it is recognized by top management, line managers and employees generally as an essential organizational process to which they are committed and in which they engage continuously. Reynolds (2004) describes a learning culture as a 'growth medium', which will 'encourage employees to commit to a range of positive discretionary behaviours, including learning' and which has the following characteristics: empowerment not supervision (as it was in those days), self-managed learning not instruction, longterm capacity building not short-term fixes. He suggests that to create a learning culture it is necessary to develop organizational practices that raise commitment amongst employees and 'give employees a sense of purpose in the workplace, grant employees opportunities to act upon their commitment, and offer practical support to learning'. Resources needed for learning should be put in place.

Developing a learning culture: The following are needed as guide lines to develop the learning culture as presented by Reynolds (2004):

1. Develop and share the vision - belief in a desired and emerging future.

2. Empower employees - provide 'supported autonomy'; freedom for employees to manage their work within certain boundaries (policies and expected behaviours) but with support available as required.

3. Adopt a facilitative style of management in which responsibility for decision making is ceded as far as possible to employees.

4. Provide employees with a supportive learning environment where learning capabilities can be discovered and applied, e.g. peer networks, supportive policies and systems' protected time for learning.

5. Use coaching techniques to draw out the talents of others by encouraging employees to identify options and seek their own solutions to problems.

6. Guide employees through their work challenges and provide them with time, resources and crucially feedback. The concept of the learning organization has caught the imagination of many people since it was first popularized by Senge (1990). He described it as one 'where people continually expand their capacity to 
create the results they truly desire, where new and expansive patterns of thinking are nurtured, where collective aspiration is set free, and where people are continually learning how to learn together'.

Pedler, Burgoyne, and Boydell (1991) state that a learning organization is one 'which facilitates the learning of all its members and continually transforms itself '. Wick and Leon (1995) refer to a learning organization as one that 'continually improves by rapidly creating and refining the capabilities required for future success. As Harrison (2000) comments, the notion of the learning organization remains persuasive because of its 'rationality, human attractiveness and presumed potential to aid organizational effectiveness and advancement'. However, Scarborough et al (1999) argue that "the dominant perspective 'of the learning organization concept' is that of organization systems and design".

7. Managers in a training and development programs in organizations act as role models. 'The new way of thinking and behaving may be so different that you must see what it looks like before you can imagine yourself doing it. You must see the new behaviour and attitudes in others with whom you can identify' (Schein, 1990).

8. Encourage networks - communities of practice.

9. Align systems to vision - get rid of bureaucratic systems that produce problems rather than facilitate work.

When little attention is paid to what individuals want to learn or how they learn by the managers of organizations, the organization will likely be considered as one which is less concern with learning and development. That organization will certainly exhibit signs of little or no productivity, thus, seen as inefficient and effective organization. Individuals should be enabled to invest in their own development; hence, a climate conducive to learning be created. A learning culture has much more to offer than that of the learning organization (Reynolds 2004). As a critique, viewing organizations as learning systems is a limited notion. Argyris and Schon (1996) contend that organizations are products of visions, ideas, norms and beliefs so that their shape is much more fragile than the organization's material structure. People act as learning agents for the organization in ways that cannot easily be systematized. They are not only individual learners but also have the capacity to learn collaboratively. Organizations therefore should be conscious of the fact that employees need development through learning systems and that not only these learning systems are the only factors enhancing effectiveness/efficiency but that organizations are products of visions, ideas, norms and beliefs.

\section{Content For Training And Development To Improve Performance}

According to Tsang (1997), setting aside the complexities of putting the lessons learnt into practice (i.e. the problem of implementation), learning will automatically lead to better performance only when the knowledge obtained is relevant. If the problem of implementation is taken into consideration as well, even relevant learning is neither a necessary nor a sufficient condition for improving performance. Harrison (2005) posed the question on what the training and development implications of such research are, and answered it as follows: It has not yet yielded enough clear evidence of a direct link between individual learning and improvements in organizational performance. However training and development activity do consistently emerge as a crucial intervening factor. According to studies carried out by Purcell, Kinnie, Hutchinson, Rayton, and Swart (2003), human resource practices were identified as being particularly powerful in influencing employee attitudes and creating positive discretionary behaviour in careers (in the sense of a 'developing future') and training. In other words, the training and development processes that help to activate the people performance link are those that 'hold the promise of learning to do things better, or doing new things'. It is the sense of progression and purpose that is important, especially in linking organizational commitment' to learning and development. In line with these arguments, training, learning and development in organizations are expected therefore to be relevant and must address the needs, goals and objectives of the organization concerned.

\section{Problems Encountered In Training and Development}

Generally, there is no organization made of humans that does not have conflicts and problems. The conflicts that are the best part of career consequences are those that take place between employees and their bosses. The number one reason people leave their jobs is conflict with their bosses. The author, of workplace relationship authority, and executive coach, Dr. John Hoover (no dates) points out that, "tempting as it is, nobody ever enhanced his or her career by making the boss look stupid." Training an employee to get along well with authority and with people who entertain diverse points of view is one of the best guarantees of longterm success. Talent, knowledge, and skill alone will not compensate for a sour relationship with a superior, peer, or customer (Tannenbaum and Yukl, 1992).

Training and Development As An Influencing Factor To Efficiency And Effectiveness In Cameroon

Mbua (2003) present three major mechanisms through which administrator/teacher competence and skills are generally acquired in Cameroon They are: education, experience and mentor/mentee relationship.

Education: According to Mbua (2003), this involves undertaking or undergoing undergraduates and or graduates studies with offerings in educational administration and planning for administrators or courses in teacher training institutions for teachers. It can also mean undergoing graduates or undergraduates courses in subject(s) which a teacher teaches'. Education can also take place when an administrator or teacher constantly attends short in-service courses and workshops or seminars. Mbua observed that in Cameroon context, the acquisition of administrative skills by practicing educational administrators seems to be predominantly through experience and understudy; and to a much lesser extent, through specialized preparation or training in educational administration. Mbualamented as he continued to states that 'principals are appointed from a pool of graduates' teachers with teaching qualification but without specialized preparation in educational administration'. This holds mostly for public schools principals. The situation in private institution is even worst as principals appointed might not have even passed through a teacher training college. He advocated that there is a need to prepare educational administrators with the appropriate mix of technical, human and conceptual skills. All these skills can only be gotten through education. 
Experience: This involves exposing to a variety of situations, problems and demands. It involves time and entails maturity on the job (ibid). This is what majority of school administrators in Cameroon has and more especially, administrators of the private sector.

Mentor/mentee relationships: This involves a young administrator/teacher learning a set of administrative/teaching skills by observing, working with, and relating to a more seasoned higher administrator/teacher. It entails learning on the-job. This connotes 'understudy' or 'internship', which is the deliberate way of acquiring skills and experience by the would-be administrator (Ibid).

\section{PCC Personnel development as a tool to enhance productivity in PCC}

PCC in general, train her workers. She has procedures for training of her workers. Further training of personnel is approved by the church's hierarchy (committee of the ministry). This is done after consultation with the head of department/unit concerned. These are the conditions for a worker to be granted permission to study:

1. The field of study should conform to the human resources development agenda. Each year the department head circulates a list of priority areas of studies for interested candidates to consider in their career progression plan.

2. The one initiating the training should be certain that the institute offering the course is accredited. The head of unit/service is expected to comment on the applicant's request and forward the letter to the Synod Clerk and Secretary Committee of the Ministry. Another copy is forwarded to the Financial Secretary. Authorization to study is done by the Secretary Committee of the Ministry or the Synod Clerk. The letter of study leave is issued. The Scholarship Secretary is expected to be in the loop of the process (PCC, 2017).

The Concept of Productivity.

Productivity generally is an index, used to measure output per unit of input (Ulasi, 2011). Productivity is the efficient use of resources - labour, capital, materials, energy, information, in the production of goods and services (Shrestha, 2005). It is difficult to talk about productivity without addressing production. Generally, there is a common thinking that the productivity concept is applied in manufacturing systems only. Nowadays, the word productivity is used in the service sector as well as in the manufacturing sector. The service sector in terms of industrial classification includes finance and insurance, real estate, transportation and communication services and electricity, gas and water supply services and educational institutions. The application of the productivity concept is widely observed in the service sector these days, especially in the information related business (Shrestha, 2005). It simply tells whether or not factors of production are contributing more or less to total output.

Productivity also as a concept is not only applied in the manufacturing industrial sector but it is perfectly applied in educational and other institutions. The educational sector in general as any other production sector, function as input which comes from the society, is transformed. In schools, this is using the processing process and the output is send back to the society which in this case are more of humans.
This is illustrated in figure 1, as a cycle-like framework depicting the educational institutions as a production function.

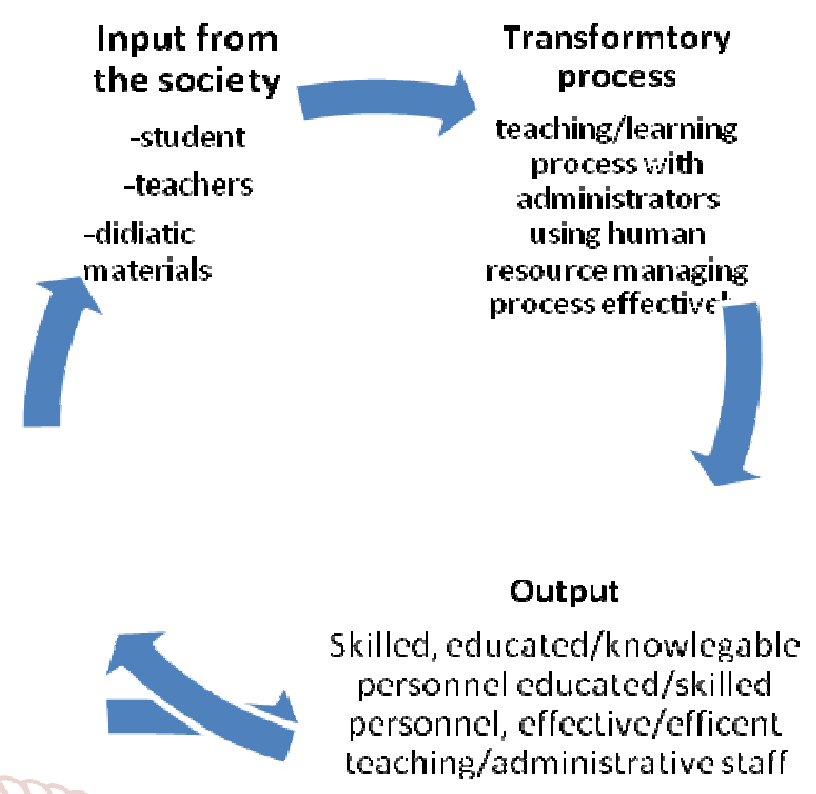

Figure 1. Productivity cycle

In the context of this study, the factors of production comprise of the following processes: planning, recruitment/selection, personnel development, personnel appraisal and motivation/wages and trade unions. It should be noted that this work or study limit the variables personnel development. Production generally means application or use of processes to the raw material to arrive at a desired product by the best method(s), without sacrificing the desired quality. In our context, it means application or manipulation of the human resource management processes (by any stakeholder) in order to yield the desired results. It also means manipulation of inputs (teachers, books, teaching and learning materials, students, administrators, resources etc,) by stakeholders to produce desired or skilled output (learned/educated skilled personnel) for use in the society. It will be worthwhile to state how productivity in general can be measured. This will help to situate discussions.

\section{School effectiveness as an indicator to productivity}

Glickman 1985 presented studies of the mid-1970s and 1980s which focused on individual schools that were exceptional. These schools according to Glickman consistently achieve results with students far superior to those of schools in general. These schools were not different from other less effective ones. Whether they were in the urban or rural areas, they still succeeded while others fail. He continued to affirm that effective schools have faculties with a clear and collective purpose toward which they work. Workers believe in 'a course beyond oneself' as the norm. Coleman, Campbell, Hobsom, McPartland, Mood, Weinfield and York (1966) found out that effective schools were distinguished by the presence of:

1. Strong leadership

2. A climate of expectation

3. An orderly but not rigid atmosphere

4. Communication to students of the school's priority on learning the bases

5. Diversion of school energy and resources when necessary to maintain priorities 
6. Means of monitoring student (and teacher) achievement (Edmonds 1979)

7. An emphasis on academics

8. Teacher' believe that students could master the subjects and (Brookover, Beady, Flood, Schweiter, Wisenbaker 1979)

Glickman 1985 presented teacher, administrator and students activities and commitments of an effective school. They are: teacher freedom in planning his/her course; agreed discipline on the side of students; goal congruence between teachers, administrators, students and parents; staff having little concern about violence, discipline and management; instead, their concern is with the school's educational priorities; schools that provide autonomy as well as involvement in educational decisions; teachers spent more time in instruction and students spent more time in learning tasks.

According to (Cappelli and Crocker-Hefter1996), distinctive human resource practices shape the core competencies that determine how firms compete. Extensive research has shown that such practices can make a significant impact on firm performance. HRM strategies therefore aim to support programmes for improving organizational effectiveness by developing policies in such areas as knowledge management, talent management and generally creating a great place to work'. This is the 'big idea' as described by Purcell, Kinnie, Hutchinson, Rayton, and Swart, (2003), which consists of a 'clear vision and a set of integrated values'. More specifically, HR strategies can be concerned with the development of continuous improvement and customer relations policies. Continuous improvement leads to productivity (effectiveness and efficiency) of an organization.

Productivity Measurement In Educational Institutions. To measure the performance/productivity of an educational institution one must know the objectives of the system, output of the system, how the services are produced and what the required resources are.

\section{Objectives of Educational System}

Overall objective of the educational system is to promote welfare of the society by improving the quality of human resources produced in educational organizations. This is a long-term objective and its achievement cannot be judged in the short-term, therefore other short-term measures that are indicative of long-term results should be started. One of these short term measures in this study is wages/motivation of workers.

Mission assigned to the Cameroon educational system is stipulated in the laws of 1998 and 2001 which are converged into the following objectives:

1. The training of citizens, who are rooted in culture, but open to the world and respectable of the general interest and of the common goal;

2. The promotion of science, culture and social progress;

3. The solidifying of the sense of ethnics and of natural consciousness

4. The promotion of democracy and of the development of a democratic spirit

5. The training and improvement of the managerial staff

6. The promotion of bilingualism and the mastering of indigenous languages

7. The search for excellence in every field of knowledge
8. The physical, sporting, artistic and cultural training of the child

9. The promotion of hygiene and health education

10. The education of the family.

The objectives of education as stated in the Cameroon laws above needs revision in the present era. In order to face the challenges of the present era of high and sophisticated technology, laws of education should be directed towards societal needs within and out of Cameroon. Objectives of education should be formulated using science, technology, engineering, and Mathematics (STEM) as goals to achieve. This implies that the structure of the entire educational sector of Cameroon needs reconstruction in her policies and curriculum, which will affects the content of what is being taught, methods of teaching, teaching materials, change in the various laboratories to meet the needs of the present era, thereby assuring greater productivity in the nearest future. The educational system generally is a set of interrelated parts aimed at improving the knowledge and skills of students and producing graduates with certain defined level of capability (Shrestha, 2005). The input is gotten from the society, transformed in schools and send back into the society as output. The output is expected to be functional and employable. But if it does not have the skills required for the job market, it is assumed that there is something wrong within the process of transformation which needs urgent adjustment. If need be, the dysfunctional output can be send back to school as input. It is a cycle.

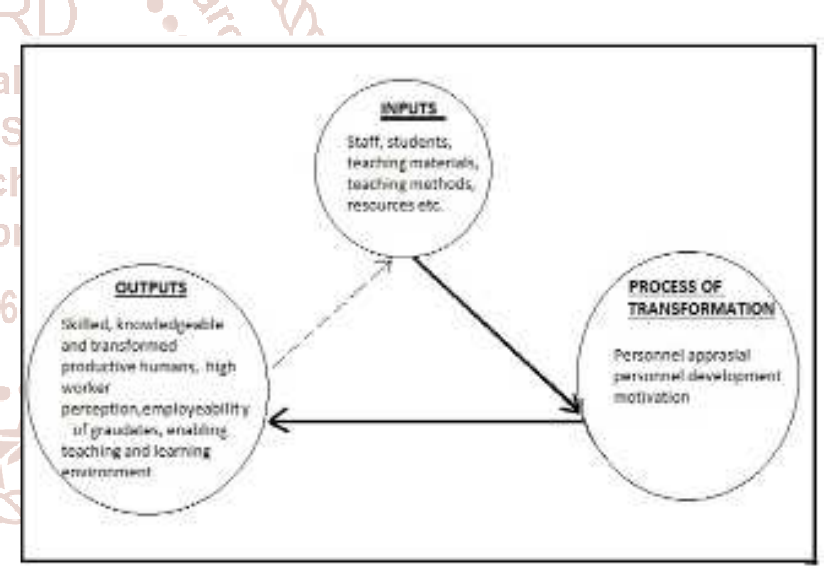

Figure 2: Conceptual framework depicting the system productivity cycle

\section{Productivity In Cameroon Educational System}

Productivity of the Cameroon educational system according to the draft document of the sector wide approach/education has some major issues in its internal and external efficiency. But for the scope and limitation of this research, the researcher will limit her discussions with the internal efficiency.

Considering the secondary level of the year 2003/2004, averagely the public sector had 61 students per class while the private sector had 38. The ratio of student per seat in specialized courses (science laboratories, computer sciences and language classes) is $1: 100$ for public and $8 / 100$ for private (1:13). There was an acute shortage of teachers for languages at the first cycle of secondary level. The average daily schedule is 5 hours and 29 hours far from the required 22 hours. The problem at that time was worst for Mathematics with daily schedule of 32 and 28 hours respectively. 
For basic commodities, secondary level of education in Cameroon is also below standard generally as of 2004 . Secondary education suffered from the shortage of receptive infrastructure, basic commodities and teaching personnel for French, English and Mathematics. One of those issues was the working condition of teachers. It was stated in the document that Cameroon teachers are generally demotivated and feel dissatisfied with a profession that no longer guarantees an image-enhancing social status. Cut of salaries of teachers also caused the drastic drop in academic standards. Teachers generally have the feeling that their leaving standard has dropped in relation to the gross national product (GNP) per person and in relation to other professions that had comparative end-of-career indices before, whereas prices of goods in the market keep on increasing.

Another point raised by the document of the sector wide approach is that the contribution of the state in financing education is low whereas that of the parents is very high. The budget allocation for education in Cameroon is very low as compared to that of other countries (Draft Document of the sector wide approach/education: Working document). All these reveal that there is a huge problem in productivity as far as the Cameroon educational system is concerned in general. To address all these, the researcher will have to start from the Presbyterian secondary schools in Cameroon since she helps the government of Cameroon in the prevision of education to her citizens. The researcher attributes the management of human resources management process to be the cause of this poor productivity in Cameroon educational sector in general.

\section{Evaluation of Presbyterian secondary schools in Cameroon}

In 1949 after the first secondary schools in Cameroon owned by the Catholic Church (St. Joseph College Sasse), the Basel Mission opened her first secondary school; Cameroon Protestant College Bali (CPC). Since then, the PCC has 25 secondary schools between 1949-2018; a period of 69 years as demonstrated in table 1.

Table 1: Presbyterian secondary schools in Cameroon from 1949 to 2019

\begin{tabular}{|l|l|l|l|}
\hline \multicolumn{2}{|c|}{ Secondary Schools } & Region & Year of Creation \\
\hline 1 & Cameroon Protestant College (CPC) Bali & NW & 1949 \\
\hline 2 & Presbyterian High School (PHS) Kumba Scien & SW & 1963 \\
\hline 3 & Presbyterian High School (PHS) Besongabang & SW & 1964 \\
\hline 5 & Presbyterian High School (PHS) Batibo & NW & 1972 \\
\hline 6 & Presbyterian Secondary School (PSS) Mankon & NW & 1978 \\
\hline 7 & Presbyterian Teacher Training College (PTTC) Mbengwi & NW & 1981 \\
\hline 8 & Presbyterian Comprehensive High School (PCHS) Kumbo & NW & 1986 \\
\hline 9 & Presbyterian Secondary School (PSS) Bafut & NW & 1988 \\
\hline 10 & Presbyterian High School (PHS) Andek esearCh and & NW & 1990 \\
\hline 11 & Presbyterian Secondary School (PSS) Nkambe & NW & 1990 \\
\hline 12 & Presbyterian Comprehensive Secondary School (PCSS) Buea. & SW & 1993 \\
\hline 13 & Presbyterian Girl's Secondary School (PGSS) Limbe 70 & SW & 1999 \\
\hline 14 & Presbyterian Secondary School (PSS) Wum & NW & 1999 \\
\hline 15 & Presbyterian Secondary School (PSS) Nkwen & NW & 2001 \\
\hline 16 & Presbyterian High School (PHS) Mbengwi & NW & 2005 \\
\hline 17 & Presbyterian Secondary School (PCSS) Douala & Littoral & 2007 \\
\hline 18 & Presbyterian Comprehensive Secondary (PCSS) Munyenge & SW & 2008 \\
\hline 19 & Presbyterian Comprehensive Secondary School (PCSS) Fiango & SW & 2008 \\
\hline 20 & Presbyterian Comprehensive Secondary School (PCSS) Azire & NW & 2008 \\
\hline 21 & Presbyterian Comprehensive Secondary School PCSS) Bangem & SW & 2013 \\
\hline 22 & Presbyterian Comprehensive Secondary School PCSS) Ndop & NW & 2013 \\
\hline 23 & Presbyterian Secondary School (PSS) Garoua & North & 2015 \\
\hline 24 & Presbyterian Secondary School (PSS) Nguoaundere & Adamawa & 2017 \\
\hline 25 & Presbyterian Comprehensive Secondary School (PCSS) Yoaunde & Centre & 2018 \\
\hline
\end{tabular}

From table 1, PCC has 14 secondary schools in the NW region, 1 in Littoral, 8 in the SW region, 1 in the North, 1 in Adamawa region and 1 in Centre region. Out of this number of secondary schools, only 6 out of 13 , in the North West and 3 out of 8 in the SW are effective. The rest are dying because of lack of student population partially due to the sociopolitical tension in the regions. PCC can be proud of only two schools in the South west region with encouraging student population. This influences productivity in the sense that the expected population of students where fees should be collected in order to pay and motivate teachers to put in their best is affected.

Even though the PCC had her independence in 1957, the Basel mission officially handed the educational sector to the
PCC in 1968. The total number of school children handed to the church was 59.015 as compared to the number of primary school pupil in 2017 with the total of 24.613 (PCC Dairy, 2017). Three secondary schools were handed over to the PCC as well having a student population of 601 taught by 30 teachers. This gives a teacher student ratio of 1:20. From table 2 above, PCC has been able to add 22 secondary schools to the three originally handed over to her by the Basel Mission.

It should be noted that the researcher brings in the situation of the drop in population in primary schools because it has effects on the population of secondary schools. Primary schools are considered as feeders to the secondary level. This is a call for concern. Teachers can be developed, 
motivated and appraised to produce the desired results but if the children are not there, there is still a big problem. One can read a drastic drop in the number of children in Presbyterian primary schools. The proliferation of many primary and secondary schools by lay private, Government and other confessional churches like the Baptist, Full Gospel and Roman Catholic has contributed to this drop. Presently, the drop is caused by the socio-political tension in Cameroon. This has made the church to hand over many of her schools to presbyteries and local congregations to manage.

Since the promulgation of the private education law, there have been two important take-overs of Presbyterian primary schools by Government. The first was in 1977 and the second take over were termed border schools. This second exercise was carried out in 1981. The reason for the latter take-over was on the request of the villagers from villages in which these schools operating. They wanted to benefit from free education offered by the government. The request was not based on poor school administration as demanded by the law but was rather on the urge for equitable distribution of government facilities. The villages wanted to enjoy free education. They did not want to pay fees in church schools as is the case revealed by $\mathrm{Nku}$ (1982).

Teachers in church schools also were anxious to become government school teachers in order to enjoy all the advantages as government workers if their schools were handed over to the government. It is noted that if nothing is done to improve the condition of teachers in church schools, the villagers and teachers will always prefer schools be handed to the government. It is very evident today where teachers of mission schools are struggling to leave mission to government.

Nku, (1982) predicted that if something is not done by the church to improve the situations of teachers, "the Presbyterian Church may, during the next 25years, to think of either abandoning participation in education on the basis or retaining good quality education which will certainly be very expensive and capable of being borne by only the rich". It is very glaring in our present day PCC educational sector whereby the poor teachers in the educational sector and some PCC Christians cannot afford to send/sponsor children to PCC owned schools. Majority of her teachers have left and some drifted to the government. The Church is presently experiencing serious problems in her educational sector caused by the socio-political tension in the country. She has suspended many of her schools and handed some to congregations to manage them as earlier mentioned. One wonders how effective congregational management will be! The government may take-over some Presbyterian secondary schools if the problem of enrolment is not addressed properly.

Nku (1982) states that the number of schools handed by the Basel Mission to the PCC in 1966 were as follows:

Table 2: Number of schools handed over to the PCC by the Basel Mission

\begin{tabular}{|c|c|c|c|c|}
\hline Type of education & No. of schools & Enrolment & No of teachers & Govt. grants \\
\hline Primary & 234 & 40.845 & 1.414 & 91.610 .821 \\
\hline Secondary & 3 & 601 & 30 & 14.186 .504 \\
\hline Teacher training & 3 & 469 & 27 & 29.198 .742 \\
\hline
\end{tabular}

Source: Nku (1982). Journey in Faith: The story of the Presbyterian Church in Cameroon. Buma Kor \& Co. Yoaunde

Nku (1982) went further to explain table 3 as follows: While primary and secondary schools were allowed to collect school fees to augment the Government-grant-in-aid in order to pay teachers'/tutors' salaries, Government paid the full salary bills of Teachers Training Colleges. The full boarding cost of Teacher Training Colleges was also paid for by government in capitation grants. At that period, the teacher/student ratio was 1:20 in secondary schools

The PCC took over three secondary schools. Parents made more sacrifices to send their children to secondary schools because of the high demand for secondary education. Parents paid fees and equipped their children to study at secondary level. The scramble for places in the few secondary schools pushed the education authority of the PCC to open more schools in Mbengwi in 1969 and Mankon in September 1978 respectively (ibid). The Church kept on opening new secondary schools up to date. The problems of erecting new and befitting structures remain a challenge to the educational sector of the PCC. Presently PCC is running close to 25 secondary schools with one technical school inclusive. PCC has one teacher training institution as of 2017 (PCC Diary, 2018).

The Church has run schools from 1886 after taking over from the English Baptist. The development of schools in terms of population of students, teachers and number of schools as presented in the dairies of the Basel Mission/PCC as follows:

\section{Presentations of the evolution of Education in the PCC} FROM 1968 to 2017

The researcher is to going to present the growth of secondary schools, students, number of schools in groups of 10years, considering only the number in the last year of the ten year period from 1968 to 2017.

Table 3: Evolution of secondary schools in terms of number, students and teachers from 1968-2017.

\begin{tabular}{|c|c|c|c|c|}
\hline YEARS & No of colleges & No of students & No of teachers & Teacher/pupil ratio \\
\hline $1968-1978$ & 4 & Missing data & Missing data & Missing data \\
\hline $1978-1988$ & 5 & 3572 & Missing data & Missing data \\
\hline $1988-1998$ & 11 & 4.794 & 244 & $1: 20$ \\
\hline $1998-2008$ & 19 & Missing data & Missing data & Missing data \\
\hline $2008-2017$ & 21 & 10.434 & 698 & $1: 14$ \\
\hline
\end{tabular}


Progressively, it is clear that secondary school level of the PCC has problems as seen in students/teacher ratio. It has never met neither the UNESCO nor Cameroon standards. Thus there is a systemic problem that needs to be addressed appropriately.

The standard teacher/student ratio in Cameroon schools is $1: 60$ in secondary levels (information gotten from the Regional Delegation of Secondary Education during interview). UNESCO in 2015 presented a maximum student/teacher ratio in Cameroon of between 41 to 45 per teacher and 62 to 72 per teacher in 2002. Comparing these ratios to that of Presbyterian secondary schools, it is clear that, productivity of teachers of the PEA is affected. Schools fees as source of income will not be enough to pay/motivate them. This will affect development of staff as resources cannot be gotten for the use of teacher's development. Thus, the internal and external efficiency of students/teachers/administrators will be influenced.

\section{Statement of The Problem}

It has been observed and experienced by the researcher that the secondary school level of the PCC educational sector is suffering from the following vices:

$>$ General drop of students' population consistently from 1998 to this present day. Between the years 2010 to 2016, the teacher pupil ratio was 1:14 (PCC dairy).

$>$ One subject master/mistress teaching from form one to upper-sixth thereby putting more hours (PCHS Kumbo, Chemistry department 2013).

$>$ Lack of training institution for secondary school teachers/administrators. One of the examples is pastors who are trained in theology and shepherding a parish suddenly become teachers and administrators in educational establishment without undergoing training in teaching and educational administration. Statistics displayed in the PCC dairy 2016 shows that out of 21 principals, only two are Master's Degree holders in educational administration, 2 with DIPES level, 7 with
Bachelors either in Arts or Science, 10 without any identification of their academic certificate.

$>$ So many teachers have not had any formal training as teachers hence, lack teaching skills. It is very possible to see educators working in health services, health workers posted to schools and clinical councillors posted to secondary schools of the Presbyterian Church in Cameroon (PCC). 'Round pegs', in 'square holes' can never fit properly.

Schools are considered as production function in the sense that input (humans and didactic materials/structures etc) comes into the system, is processed using the processing process (teaching/learning activities/administrative functions/culture etc) and produces output (skilled, educated and knowledgeable humans) ready for services in the society.

\section{Purpose of the study}

The purpose of this study was to find out whether training and development as one of the processes in human resource management process influence productivity.

\section{Objective of the study}

$>$ To assess how personnel development of workers of Presbyterian secondary schools influences efficiency/effectiveness which lead to productivity of the system.

\section{Research Methodology}

\section{Research Design}

The researcher employs a survey design. As method of collecting data, documents (church documents, reports of external results from various colleges, questionnaire and interview) were used. Data was also collected from the teachers, principals and students of Presbyterian secondary schools in the North West, South West and Littoral regions of Cameroon. The researcher collected qualitative and quantitative data by using open and closed ended questionnaire, interviews and focused group discussion.

\section{Area of Study}

Table 4: Distribution of area of study from region, division, sub divisions and PEA secondary schools

\begin{tabular}{|c|c|c|c|c|c|c|c|c|}
\hline \multicolumn{3}{|c|}{ NW } & \multicolumn{3}{|c|}{ SW } & \multicolumn{3}{|c|}{ LITTORAL } \\
\hline Divisions & $\begin{array}{c}\text { Sub } \\
\text { Division } \\
\end{array}$ & Colleges & Division & $\begin{array}{c}\text { Sub } \\
\text { Division }\end{array}$ & $\begin{array}{c}\text { College } \\
\text { (s) }\end{array}$ & Division & $\begin{array}{c}\text { Sun } \\
\text { Division } \\
\end{array}$ & Colleges \\
\hline $\begin{array}{c}\text { Donga } \\
\text { Mantung }\end{array}$ & Nkambe & PSS Nkambe & \multirow{4}{*}{$\begin{array}{l}\text { Fako } \\
\text { Fako }\end{array}$} & \multirow{3}{*}{ Buea } & \multirow{3}{*}{$\begin{array}{l}\text { PCSS } \\
\text { BUEA }\end{array}$} & \multirow{7}{*}{ Worri } & \multirow{7}{*}{$\begin{array}{c}\text { Douala IV } \\
\text { Sub } \\
\text { Division }\end{array}$} & \multirow{7}{*}{$\begin{array}{c}\text { PCSS } \\
\text { Douala }\end{array}$} \\
\hline Bui & $\begin{array}{l}\text { Kumbo } \\
\text { Central }\end{array}$ & PCSS Kumbo & & & & & & \\
\hline \multirow{5}{*}{ Mezan } & \multirow[t]{2}{*}{ Bamenda 1} & PSS Mankon & & & & & & \\
\hline & & PCSS Azarri & & Limbe & $\begin{array}{c}\text { PGSS } \\
\text { Limbe }\end{array}$ & & & \\
\hline & Bamenda 2 & PSS Nkwen & \multirow{3}{*}{ Meme } & \multirow{3}{*}{ Kumba } & \multirow{3}{*}{$\begin{array}{c}\text { PHS } \\
\text { Kumba }\end{array}$} & & & \\
\hline & Bafut & PSS Bafut & & & & & & \\
\hline & Bali & CPC Bali & & & & & & \\
\hline
\end{tabular}

Table 5: Distribution of the Target population/Sample Population

\begin{tabular}{|l|c|c|}
\hline \multicolumn{1}{|c|}{ Studied group } & Target population & Sample \\
\hline College Administrators & $\mathbf{1 0 0}$ & $\mathbf{1 0}$ \\
\hline Teachers & $\mathbf{6 9 8}$ & $\mathbf{7 0}$ \\
\hline Form five and upper sixth students of PCSS Buea/Douala and PCHS Kumbo & $\mathbf{3 0 0}$ & $\mathbf{3 0}$ \\
\hline Subtotal as per Glenn (1992) & $\mathbf{1 0 9 8}$ & $\mathbf{1 1 0}$ \\
\hline Actual sampled & & $\mathbf{1 1 0 + 5 = 1 1 5}$ \\
\hline From focused discussion/interview & & $\mathbf{4 1}$ \\
\hline Grand Total & & $\mathbf{1 5 6}$ \\
\hline
\end{tabular}




\section{FINDINGS}

Table7. Internal efficiency of college X measured through drop from school 2014/2015 academic year

\begin{tabular}{|c|c|c|c|c|c|c|}
\hline \multirow{2}{*}{$\begin{array}{c}\text { Total number } \\
\text { of students at } \\
\text { the beg }\end{array}$} & \multicolumn{5}{|c|}{ Reduction within the academic year/reasons } & $\begin{array}{c}\text { Total number of } \\
\text { students at end of } \\
\text { the academic year. }\end{array}$ \\
\cline { 2 - 7 } & Dismissed & withdrew & dead & $\begin{array}{c}\text { Inability to pay } \\
\text { fees }\end{array}$ & $\begin{array}{c}\text { Total } \\
\text { reduction }\end{array}$ & 27 \\
\hline 1124 & 12 & 7 & 1 & 7 & 27 & 1097 \\
\hline
\end{tabular}

The difference between total admitted and drop out for whatever reasons of College 'Z' of 2014/2015 academic year as seen in table 5 was 27 out of 1124 . This number is insignificant as compared to the number of students who ended up with the academic year. Thus, internal efficiency base on drop out of students is commendable.

Administrative/Teaching Staff. The college had 8 administrative staff distributed in this order:

Table 6: Presentation of college 'Z' 2015 Administrative staff/qualification.

\begin{tabular}{|c|c|c|}
\hline Number & Office & Qualifications \\
\hline 1 & Principal & DIPES/MA \\
\hline 2 & Vice Principals & B.A and B.Sc. \\
\hline 1 & Chaplain & B.Th \\
\hline 2 & Discipline Masters & M.A and B.A \\
\hline 2 & Finance Clerks & B. Sc and B.Sc \\
\hline
\end{tabular}

Table 6 present college ' $\mathrm{Z}$ ' administrative staff base on office held and academic qualifications. Administrative staff of the college has academic qualifications ranging from DIPES, Bachelors to Masters Degrees. None of the administrators has formal training on educational administration. A call for concern! Mbua (2003) pointed out that school administrator in Cameroon colleges are not trained administrators. Table 6 just supported Mbua's claim. It is likely that college ' $\mathrm{Z}$ ' administrative staff could be the general picture of administrative staff of Presbyterian secondary schools in Cameroon.

\section{Teaching Staff}

The college has 45 teaching staff with academic qualifications ranging from masters -grade 1 as displayed in table 7 below.

Table7: Presentation of 2015 teaching staff of College 'Z'.

\begin{tabular}{|c|c|}
\hline Academic Qualifications & Number \\
\hline M. A & 02 \\
\hline M.Ss & 01 \\
\hline B.A & 11 \\
\hline B.Ss & 20 \\
\hline B.Ed & 05 \\
\hline DIPES 1 & 02 \\
\hline DIPES 11 & 03 \\
\hline Dip & 01 \\
\hline Grade 1 & 01 \\
\hline
\end{tabular}

From the table 7 , out of the 45 teaching staff of college $\mathrm{Z}$, only six (6) have passed through a teacher training college with qualification ranging from grade I to DIPES II. 39 are degrees holders ranging from Bachelor to Masters Level. One can likely conclude that, majority of PEA secondary school teachers in Cameroon are not trained teachers. There was a non-teaching staff capacity of 22. They function as cooks, secretaries, drivers, security guides, electrician and baker at 2014/2015 academic year.

Measurement of internal efficiency of PEA colleges using external examinations of some selected colleges from 2011-2015

External examinations are the only means by which internal efficiency base on student's performances as far as examinations are concerned is measured. Before the presentation of external examination results, the standard grading system of the PEA colleges in Cameroon and efficiency standards set by the researcher will be presented.

Table 8: General Standard grading system of Presbyterian secondary schools 0/L Results

\begin{tabular}{|c|c|c|}
\hline Grade & Remarks & $\begin{array}{c}\text { Efficiency standards set } \\
\text { by the researcher }\end{array}$ \\
\hline A A & Excellent & Very highly efficient \\
\hline B & Very Good & Highly efficient \\
\hline C & Average & efficient \\
\hline D & Below average & Poorly efficient \\
\hline Jolna & failed & Failed institution \\
\hline Eiefific & Very poor & Failed institution \\
\hline
\end{tabular}

NB: Very efficient/ effective schools are considered to have from $B$ to A grades. $C$ grades need to work harder to be considered as effective and efficient schools and from $\mathrm{D}$ to $\mathrm{F}$ grades is considered as an ineffective and inefficient school base on external examinations.

Table9: General Advanced Level standard grading of Presbyterian secondary schools.

\begin{tabular}{|c|c|c|}
\hline Grades & Remarks & $\begin{array}{l}\text { Efficiency standards } \\
\text { set by the researcher }\end{array}$ \\
\hline A & Excellent & Very highly efficient \\
\hline $\mathrm{B}$ & Very Good & Highly efficient \\
\hline $\mathrm{C}$ & Good & efficient \\
\hline $\mathrm{D}$ & Fairly good & fairly efficient \\
\hline $\mathrm{E}$ & Average & Poorly efficient \\
\hline 0 & Below average & Failed institution \\
\hline $\mathrm{F}$ & Failed & Failed institution \\
\hline
\end{tabular}

NB. A school with the highest number of A and B grades is considered to be effective and efficient as far as internal efficiency is concerned. D and E grades is averagely good as far as internal efficiency is concerned. The quality of the results is poor even though with pass grades. 0 and $F$ qualify the school to be an inefficient and ineffective school as far as internal efficiency is concerned. These standards are used in this research to determine the Presbyterian secondary schools internal efficiency using her GCE O/L and A/L. The researcher also considered the general performance in terms of percentage and grades. 
International Journal of Trend in Scientific Research and Development (IJTSRD) @ www.ijtsrd.com eISSN: 2456-6470

Table 10: Standards set by the researcher in terms of Percentage of external examinations for internal efficiency.

\begin{tabular}{|c|c|}
\hline Percentage Range & Internal efficiency description \\
\hline $90-100 \%$ & Very highly efficient \\
\hline $80-89 \%$ & Highly efficient \\
\hline $70-79 \%$ & Efficient \\
\hline $60-69 \%$ & Fairy efficient \\
\hline $50-69 \%$ & Poorly efficient \\
\hline $49 \%$ and bellow & Failed school. \\
\hline
\end{tabular}

Table 11: Summary of 0/L 2011-2015 of some selected colleges of the PEA.

\begin{tabular}{|c|c|c|c|c|c|c|c|c|c|c|c|}
\hline \multirow{4}{*}{ Session } & \multirow{4}{*}{ Reg. } & \multirow{4}{*}{ sat } & \multirow{4}{*}{ Passed } & \multirow{4}{*}{ \%pass } & \multicolumn{6}{|c|}{ Grades $\%$} & \multirow{3}{*}{ Total } \\
\hline & & & & & \multicolumn{3}{|c|}{ Passed } & \multicolumn{3}{|c|}{ Failed } & \\
\hline & & & & & $\bar{A}$ & $\bar{B}$ & C & D & $\bar{E}$ & $\bar{U}$ & \\
\hline & & & & & 1458 & 3769 & 5841 & 1653 & 1368 & 1157 & 15246 \\
\hline 2011 & 82 & 82 & 72 & 90.24 & 15.49 & 41.37 & 43.13 & 36.23 & 27.92 & 35.05 & 833 \\
\hline 2012 & $=$ & $=$ & & $=$ & 13.12 & 36.79 & 50.09 & 43.52 & 33.60 & 22.85 & 2155 \\
\hline 2013 & 333 & 327 & 315 & 96.44 & 12.12 & 35.86 & 52.12 & 37.57 & 26.78 & 35.66 & 3345 \\
\hline 2014 & 227 & 226 & 197 & 96.03 & 13.21 & 35.95 & 50.84 & 34.44 & 28.88 & 36.65 & 2822 \\
\hline 2015 & 576 & 576 & 431 & 91.69 & 13.57 & 30.11 & 56.32 & 42.41 & 37.68 & 19.91 & 6091 \\
\hline Total & 1220 & 1211 & 1015 & 93.6 & 13.17 & 34.05 & 52.77 & 39.56 & 32.74 & 27.69 & $100 \%$ \\
\hline
\end{tabular}

The 0/L results from 2011 to 2015 shows that more than half $(52.77 \%)$ of the successful candidates scored the minimal C grade, while more than a third (34.05\%) scored Bs and just more than a tenth (13.17\%) scored the prestigious As. Among the failures, nearly two-fifths (39.59\%) scored D, about a third (32.74\%) scored E and more than a quarter (27.69\%) scored the dreaded U. The performances in college D which served as a control school for 1016 and 2017 are similar to those of 2011 2015 with $13.76 \%$ As, $36.69 \%$ Bs and $49.55 \%$ Cs for the successful candidates. On the other hand, the failures registered averages of $47.90 \%$ Ds, $31.93 \%$ Es and $20.19 \%$ Us. ernational Journal

\section{Commercial Section Ordinary level 2013-2015 of College ' $\mathrm{Z}$ '}

Table 14: Presentation of 2013-2015 ordinary level Commercial Results of college ' $\mathrm{Z}$ '

\begin{tabular}{|c|c|c|c|c|c|c|c|c|c|c|c|}
\hline \multirow{2}{*}{ Year } & \multicolumn{4}{|c|}{ General performance } & \multicolumn{3}{c|}{ Grades 447 passed } & \multicolumn{3}{c|}{313 failed } & \multirow{2}{*}{ Total } \\
\cline { 2 - 13 } & Reg. & Sat & Passed & \%Passed & A & B & C & D & E & F & \\
\hline 2013 & 41 & 41 & 34 & 82.93 & 24 & 92 & 148 & 41 & 37 & 78 & 420 \\
\hline 2014 & 16 & 16 & 10 & 62.50 & 09 & 21 & 46 & 24 & 26 & 39 & 165 \\
\hline 2015 & 20 & 20 & 19 & 95 & 16 & 15 & 76 & 28 & 13 & 27 & 175 \\
\hline Total & 77 & 77 & 63 & 81.14 & 49 & 128 & 270 & 93 & 76 & 144 & 670 \\
\hline$\%$ & & & & & 10.96 & 28.64 & 60.40 & 29.71 & 24.28 & 46.00 & 100 \\
\hline
\end{tabular}

Although the average pass rate (81.14\%) is good, it is significantly lower than that of general Education. Also, the performances of both the successful and failed candidates are comparatively lower than those of general education with $10.96 \%$ As, $28.64 \%$ Bs, $60.40 \%$ Es and $29.71 \%$ Ds, $24.28 \%$ Es and $46.00 \%$ Us.

Ordinary level Results of College 'D' for 2016 and 2017

Table 13: Presentation of College 'D' special ordinary results of 2016-2017

\begin{tabular}{|c|c|c|c|c|c|c|c|c|c|c|c|}
\hline \multirow{4}{*}{ Year } & \multirow{3}{*}{\multicolumn{4}{|c|}{ General Performance }} & \multicolumn{3}{|c|}{ Grades } & \multicolumn{3}{|c|}{ Grades } & \multirow{4}{*}{ Total } \\
\hline & & & & & \multirow{2}{*}{\multicolumn{3}{|c|}{$\begin{array}{c}\text { Passed } \\
1003 \\
\end{array}$}} & \multirow{2}{*}{\multicolumn{3}{|c|}{$\begin{array}{c}\text { Failed } \\
238 \\
\end{array}$}} & \\
\hline & & & & & & & & & & & \\
\hline & Reg. & Sat & Passed & $\%$ passed & $\mathrm{A}$ & $\bar{B}$ & C & D & E & $F$ & \\
\hline 2016 & 58 & 58 & 50 & 86.21 & 59 & 162 & 220 & 75 & 48 & 36 & 600 \\
\hline 2017 & 59 & 59 & 59 & 100 & 79 & 206 & 277 & 39 & 28 & 12 & 641 \\
\hline Total & 117 & 117 & 109 & 93.105 & 138 & 368 & 497 & 114 & 76 & 48 & 1241 \\
\hline$\%$ & & & & & 13.76 & 36.69 & 69.55 & 47.90 & 31.93 & 20.19 & \\
\hline
\end{tabular}

Although the average pass rate $(81.14 \%)$ is very good, it is significantly lower than that of general Education. Also, the performances of both the successful and failed candidates are comparatively lower than those of the general education with $10.96 \%$ As, $28.64 \%$ Bs, $60.40 \%$ Es and $29.72 \%$ Ds; $24.28 \%$ Es and $46.00 \%$ Us. 
International Journal of Trend in Scientific Research and Development (IJTSRD) @ www.ijtsrd.com eISSN: 2456-6470

Table 12: Summary of Advance Level Results of seven (7) selected PEA colleges from 2011-2015 in Cameroon.

\begin{tabular}{|c|c|c|c|c|c|c|c|c|c|c|c|c|}
\hline \multirow{4}{*}{ Session } & \multirow{4}{*}{ Reg. } & \multirow{4}{*}{ Sat. } & \multirow{4}{*}{$\overline{\text { Pass }}$} & \multirow{4}{*}{$\%$} & \multicolumn{7}{|c|}{ Grades $/ \%$} & \multirow{4}{*}{$\begin{array}{l}\text { Total } \\
1053\end{array}$} \\
\hline & & & & & \multicolumn{5}{|c|}{ Passed } & \multicolumn{2}{|c|}{ Failed } & \\
\hline & & & & & A & $\bar{B}$ & C & $\bar{D}$ & $E$ & 0 & $F$ & \\
\hline & & & & & 277 & 731 & 1145 & 1215 & 1285 & 513 & 540 & \\
\hline 2011 & 113 & 113 & 98 & 86. & 4.68 & 14.04 & 20.04 & 28.36 & 32.16 & 47.38 & 52.17 & 457 \\
\hline 2012 & $=$ & $=$ & $=$ & $=$ & 11.04 & 16.98 & 25.81 & 24.79 & 21.39 & 38.67 & 61.33 & 664 \\
\hline 2013 & 202 & 201 & 193 & 99.85 & 9.90 & 14.07 & 24.08 & 30.18 & 24.08 & 45.54 & 54.46 & 724 \\
\hline 2014 & 260 & 260 & 255 & 98.5 & 6.60 & 16.29 & 24.84 & 24.67 & 27.61 & 63.48 & 36.52 & 1406 \\
\hline 2015 & 597 & 596 & 558 & 93.69 & 3.85 & 15.55 & 24.96 & 25.71 & 29.93 & 46.23 & 57.99 & 2455 \\
\hline Total & & & & & 5.95 & 15.71 & 24.61 & 26.11 & 27.62 & 87.72 & 51.28 & $100 \%$ \\
\hline
\end{tabular}

The A/L results for general education for 2011-2015 shows that more than half (53.73\%) of the passes were either D grade $(26.11 \%)$ or Es (27.62\%). There were only 5.95\% As and $15.71 \%$ Bs. Meanwhile, more than half (53.77\%) of the failures scored Fs.

Commercial Section Advanced Level 2011-2015 of College ' $Z$ '

Table 14: Presentation of 2013 \& 2015 Advanced Level Commercial Results of college ' $Z$ '

\begin{tabular}{|c|c|c|c|c|c|c|c|c|c|c|c|c|}
\hline \multirow{3}{*}{ Year } & \multirow{2}{*}{\multicolumn{4}{|c|}{ General Performance }} & \multirow{2}{*}{\multicolumn{5}{|c|}{$\begin{array}{c}\text { Grades } \\
\text { Pass } 262\end{array}$}} & \multirow{2}{*}{\multicolumn{2}{|c|}{$\frac{\text { Failed }}{66}$}} & \multirow{3}{*}{ Total } \\
\hline & & & & & & & & & & & & \\
\hline & Reg. & Sat & Passed & $\%$ Passed & A & B & C & D & E & 0 & $F$ & \\
\hline 2013 & 24 & 24 & 24 & 100 & 16 & 12 & 20 & 13 & 28 & 09 & 06 & 104 \\
\hline 2015 & 47 & 47 & 46 & 97.87 & 32 & 31 & 40 & 27 & 43 & 20 & 31 & 224 \\
\hline Total & 71 & 71 & 70 & 98.935 & 48 & 43 & 60 & 40 & 71 & 29 & 37 & 328 \\
\hline$\%$ & & & & 5 & 18.32 & 16.41 & 22.90 & 15.27 & 27.10 & 43.94 & & \\
\hline
\end{tabular}

The results of GCE A/L commercial manifest the following characteristics: Passes- $18.32 \%$ As; $16.41 \%$ Bs; 22.9 Cs and $15.27 \%$ Ds; $27.10 \%$ Es. Failures-56.06\%Fs and $44.94 \%$ Os. All these shows that the results are quantitatively very high and qualitative Low. If the productivity of the Presbyterian secondary schools is measured using GCE results, then two major issues shall arise:

Results by percentages are apparently good (above $80 \%$ ) see table 11-23.

Results by grades are very poor (about $60 \%$ with $C$ grades).

College 'Z' has 45 teaching staff with academic qualifications ranging from masters -grade 1 (see table 5).

Analysis of 0/L results of some selected colleges from 2011-2018 gives an average percentage passed of 91.44. Quantitatively, as far as external examinations are concern, PEA secondary schools are highly efficient. Qualitatively, ordinary results cannot qualify the PEA secondary as efficient internally.

Same holds with GCE Advance level from 2011-2017. Quantitatively, the results are excellent and one can be tempted to qualify the PEA colleges as efficient as far as external examinations are concern. The average percentage score for a period of five years for seven selected colleges is 94. Qualitatively, the A/L results cannot qualify PEA second cycle schools as efficient

From the quality of staff in terms of qualification as demonstrated in table 6, one expects excellent results. However, the quality of staff in terms of profession is less. Only few went to teacher training college. Results from respondent from the field as seen in table 36 . While more than two-fifths (44.74\%) of the respondents are holders of the Bachelors' degree, almost one quarter of respondents (23.64\%) are trained teachers from either ENS Bambili or ENIET Mbenqwi and less than one-fifth are masters degree holders $(14.55 \%)$.

Table 15: Description of findings in relation to Personnel development as an influencing factor to productivity.

\begin{tabular}{|c|c|c|c|c|c|c|c|}
\hline \multirow{3}{*}{ S. $\mathbf{N}$} & \multirow{3}{*}{ Statements } & \multicolumn{5}{|c|}{ Response Options } & \multirow{3}{*}{$\begin{array}{c}\text { Mean } \\
\text { Values } \\
\sum \mathrm{R} w / \mathrm{nR} \\
\end{array}$} \\
\hline & & \multicolumn{2}{|c|}{ Agree } & & \multicolumn{2}{|c|}{ Disagree } & \\
\hline & & SA (4) & $A(3)$ & $N(0)$ & $\mathrm{D}(2)$ & SD (1) & \\
\hline 1 & $\begin{array}{l}\text { Teachers are trained before he/she start } \\
\text { to work to ensure effectiveness/efficiency }\end{array}$ & $\begin{array}{c}20 \\
(80)\end{array}$ & $32(96)$ & $\begin{array}{c}8 \\
(0)\end{array}$ & $\begin{array}{c}36 \\
(36)\end{array}$ & $\begin{array}{c}2 \\
(2)\end{array}$ & 2.40 \\
\hline 2 & $\begin{array}{l}\text { Teachers are trained while working to } \\
\text { develop their capacities for effectiveness }\end{array}$ & $\begin{array}{c}10 \\
(40)\end{array}$ & 66 (198) & $\begin{array}{c}4 \\
(0)\end{array}$ & $\begin{array}{c}20 \\
(40)\end{array}$ & $\begin{array}{c}6 \\
6 \\
(6)\end{array}$ & 2.73 \\
\hline 3 & $\begin{array}{l}\text { Teachers are trained based on needs to } \\
\text { ensure that the rights persons are train to } \\
\text { meet the needs of students academic } \\
\text { performance }\end{array}$ & $\begin{array}{c}16 \\
(64)\end{array}$ & $\begin{array}{c}40 \\
(120)\end{array}$ & $\begin{array}{c}6 \\
6 \\
(0)\end{array}$ & $\begin{array}{c}34 \\
(68)\end{array}$ & $\begin{array}{c}6 \\
6 \\
(6)\end{array}$ & 2.95 \\
\hline 4 & $\begin{array}{l}\text { Teachers/administrators are given in- } \\
\text { service training to ensure effectiveness }\end{array}$ & $\begin{array}{c}16 \\
(64)\end{array}$ & $44(132)$ & $\begin{array}{c}6 \\
(0)\end{array}$ & $\begin{array}{c}18 \\
(36)\end{array}$ & $\begin{array}{c}6 \\
(6)\end{array}$ & 2.73 \\
\hline 5 & $\begin{array}{l}\text { Research allowance is provided to enable } \\
\text { teachers to do research and upgrade their } \\
\text { skills as a facet to effectiveness }\end{array}$ & $\begin{array}{c}2 \\
(8)\end{array}$ & $30(90)$ & $\begin{array}{c}8 \\
(0)\end{array}$ & $\begin{array}{c}24 \\
(48)\end{array}$ & $\begin{array}{c}46 \\
(46)\end{array}$ & 1.75 \\
\hline
\end{tabular}


International Journal of Trend in Scientific Research and Development (IJTSRD) @ www.ijtsrd.com eISSN: 2456-6470

\begin{tabular}{|c|c|c|c|c|c|c|c|}
\hline 6 & $\begin{array}{l}\text { Facilities geared towards facilitating } \\
\text { research such as computers and internet } \\
\text { are made available to ensure teacher } \\
\text { development }\end{array}$ & $\begin{array}{c}2 \\
(8)\end{array}$ & $30(90)$ & $\begin{array}{c}8 \\
(0)\end{array}$ & $\begin{array}{c}48 \\
(96)\end{array}$ & $\begin{array}{c}16 \\
(16)\end{array}$ & 2.02 \\
\hline 7 & $\begin{array}{l}\text { The library is well equipped to facilitate } \\
\text { research assisting in teacher development }\end{array}$ & $\begin{array}{c}2 \\
(8) \\
\end{array}$ & $40(120)$ & $\begin{array}{c}4 \\
(0) \\
\end{array}$ & $\begin{array}{c}20 \\
(40)\end{array}$ & $\begin{array}{c}28 \\
(28) \\
\end{array}$ & 2.09 \\
\hline 8 & $\begin{array}{l}\text { The library is well equipped to facilitate } \\
\text { research to promote teacher development }\end{array}$ & $\begin{array}{c}10 \\
(40)\end{array}$ & $40(120)$ & $\begin{array}{l}12 \\
(0)\end{array}$ & $\begin{array}{c}22 \\
(44)\end{array}$ & $\begin{array}{c}20 \\
(20)\end{array}$ & 2.15 \\
\hline & Total & $\begin{array}{c}78 \\
(312) \\
\end{array}$ & $\begin{array}{c}322 \\
(966) \\
\end{array}$ & $\begin{array}{l}56 \\
(0) \\
\end{array}$ & $\begin{array}{c}202 \\
(404) \\
\end{array}$ & $\begin{array}{c}128 \\
(128) \\
\end{array}$ & $\begin{array}{c}786 \\
1810 \\
\end{array}$ \\
\hline & & $\begin{array}{c}200 \\
(50.9 \%)\end{array}$ & $7.1 \%$ & $\begin{array}{c}165 \\
(42.0 \%)\end{array}$ & & & \\
\hline \multicolumn{7}{|c|}{ Mean Value } & 2.30 \\
\hline
\end{tabular}

Section 2/2: Personnel Development.

\begin{tabular}{|c|c|c|c|}
\hline Mean opinion & Percentage Agree & Percentage Disagree & Percentage of indecision \\
\hline 2.30 & 50.9 & 42.0 & 7.1 \\
\hline \multicolumn{2}{|c|}{ Number of Response $=97$} & \multicolumn{2}{|c|}{ Critical mean value $=2.00$} \\
\hline
\end{tabular}

In reaction to the issues raised in connection to the influence of personnel development of workers of PCC secondary schools, $(50.9 \%)$ of the respondents agree while $(42.0 \%)$ disagree and (7.1\%) are undecided. A mean value of $2.30 \%$ and $50.9 \%$ agreement show that the respondents only averagely agree. This also implies that the conditions under which workers of the PCC secondary schools are developed are just slightly above expectations. Out of the eight items in relation to personnel development as influence to productivity which were above the critical value, one item was below the critical value with the mean value of 1.78 . This was in disagreement that research allowance is given to workers of the Presbyterian secondary schools in Cameroon.

\section{DISCUSSIONS/RECOMMENDATIONS}

Progressively, it is clear that PCC educational sector has problems as seen in students/teacher ratio (table 4). It has never meet up to neither UNESCO nor Cameroon standards. Thus a systemic problem that needs to be addressed appropriately. Average teacher/students ratio is 1:14 as of 2016. Considering her teacher pupil ratio, it is clearly seen that the PEA secondary school level can NOT be able to raise enough money to pay her workers from school fees if that is the only source of income. PEA staff normal wages cannot be regularly paid. This confirms the problem seen and raised at the beginning of this research. If normal wages are not paid, it's just logically clear that motivation/development of workers will not be effective. Thus, the internal and external efficiency of both students/teachers/administrators are negatively affected thereby affecting the productivity of the sector in general.

\section{Internal Efficiency Measurement Administrative staff}

Administrative staff of the college has academic qualifications ranging from DIPES, Bachelors to Masters degrees. None of the administrators has formal training on educational administration. A call for concern! Mbua (2003) pointed out that school administrator in Cameroon colleges are not trained administrators. It is likely that college ' $\mathrm{Z}$ ' administrative staff could be the general picture of administrative staff of Presbyterian secondary schools in Cameroon.

\section{Teaching Staff}

Majority of the respondent were holders of a bachelor's degree $(44.74 \%)$, almost one quarter of respondents are trained teachers (23.64\%). An insignificant number of respondents' indicated that they have in-service training $(2.92 \%)$. By assumption, one can conclude that the Presbyterian secondary schools staff is highly qualify with good mastery of the subjects and knowledge. This is one of the prerequisite of a teacher as stated by Mbua (2003). However, lacks teaching skills somehow since majority of PEA teachers has not gone to teaching training colleges. Thus, poor internal efficiency as teaching skills is concerned. If the productivity of the Presbyterian Secondary Schools is measured using GCE results, then two major issues shall arise:

Results by percentages are apparently good (above 90\% each time averagely). Results by grades are very poor (about $60 \%$ with $\mathrm{C}$ grades). The same holds for $\mathrm{O} / \mathrm{L}$ Commercial and both A/Ls general/commercial. This implies that, there is a need of human resource management process, with the proper/effective use of personnel appraisal, personnel development and motivation as some of the influencing factors to effectiveness/efficiency in terms of results. The numbers of passed grades are more than the numbers of failed grades. However, to strongly state that an educational institution is efficient, one expect to see majority of students scoring A and B grades at the end of course examinations. This has not been the case with grades of candidates from selected Presbyterian colleges. Commercial GCC results need improvement in performance to be qualified as an effective and efficient institution leading to productivity in this aspect. Special college 'D' 2015-2017 results used as control school proved that Presbyterian secondary schools needs great improvement as far as external examination in terms of quality are concern. The results were not much different from other selected colleges for a five years period.

\section{Recommendations}

1. Personnel development as a process in human resource management influencing productivity.

2. Administrators training be included in the ISTP programme and administrators be sent for further studies in Educational Administration at the University of Buea or any other university that offers such training. This is in line with Mbua (2003) when he advocated that there is a need to prepare educational administrators with the appropriate mix of technical, human and conceptual skills. All these skills can only be gotten through education. 
3. Sharpening of skills of PEA workers should be a top priority as a factor to activate the worker performance aimed at 'learning to do things better or do new things' ( Mbua 2003 and Kinnie et al 2003).

4. PEA should facilitate learning of all her staff members (Peddler 1991). Introducing, eliminating, modifying, directing and guiding processes of Watson (2005) should be adopted by the PEA training and development team.

5. Very senior, experienced professionally trained teachers/ administrators should be identified by the PEA for ISTP programs. These groups of persons should not only be professionals in teaching methods but they should also be masters of the subjects/curriculum content in secondary schools. Teachers be sent to upgrade their

6. Work load be reduced and time set aside for teacher development. A monitoring team be put in place as a follow up to ensure teachers are selected and developed.

7. The PCC should open a training institution for secondary school teachers

\section{REFERENCES}

[1] Amstrong, M. (2006). A Handbook of Human Resource ManagementPractice. (10 ${ }^{\text {th }}$ ed.), London: Kogan.

[2] Armstrong, M. (1999). A Handbook OfHuman Resource Management Practice (7th ed.), London: Kogan.

[3] Brookover, W., Beady, C., Flood, P., Schweiter, J., and Wisenbaker, J. (1979).School social systems and students achievement: Schools can make a difference. New York: Praeger Cameroon. Law No98/004 of $14^{\text {th }}$ April 1998 to regulate the running of nursery, Primary, secondary and teacher education.

[4] Cappelli, P. Crocker-Hefter, A. (1996). Distinctive human resources are firms core Competencies. Organizational Dynamic: 24(3).

[5] Coleman, J. S.; Campbell, E. Q.; Hobson, C. J.; McPartland, J.; Mood, A.M.; Wein, F. D.; and York, R. L. (1966). Equality of educational opportunity. Washington, D. C.: U.S. Government Printing office.

[6] Dearden, L., Reed, H. and Reeneen, J.V. (2005). The Impact of Training on Productivity \& Wages: Evidence From British Panel Data. Centre for Economics Performance: CEP discussion paper No 674 .

[7] Edith, E. (2012). English and French pedagogical cultures: convergence and divergence in Cameroonian primary school teachers' discourse. Journal of comparative education, Volume 43, P 303-321 | Published online: 16 Jan 2012

[8] Faruk, B., Mustafa, M., Chowdhury, Farzana F. (2014). Historical Evolution of Human Resource Information System (HRIS): An Interface between HR and Computer Technology, Human Resource Management Research, Vol. 4 No. 4, pp. 75-80. doi: 10.5923/j.hrmr.20140404.01.

[9] Fonkeng, G. E. (2011). The History of Education in Cameroon (1844-2010). Maryland Printers: Bamenda.

[10] Glickman, C. D., (1985). Supervision of instruction a development approach. Boston: Ally \& Bacon.

[11] Harrison, R (2005). Learning and Development, 4th edn, CIPD, London
[12] Harter, S (1978). "Effectance motivation reconsidered: Toward a developmental model". Human Development: 1, 661-669.

[13] Harrison, R (2005). Learning and Development, 4th ed., CIPD: London

[14] Hellerstin, J.K., Neumark, D. \&Troske, K.R. (1999). Wages, productivity \& worker characteristics: evidence from plant-level production functions and wage equation: Journal of labour Economics. Vol. 17(3), 409446. Date accessed Jan 17th 2018.

[15] Mac0jong, T.T. (2008). Philosophical and historical foundations of education inCameroon. Design House: Limbe

[16] Mbua, F. N. (2003). Educational Administration: Theory and Practice The management of Organization and individuals. Limbe: Press Print-Cameroon.

[17] Moritti, E. (2004). Workers Education, Spill overs and Productivity: Evidence from Plant-level Productive Function. America Economic Review, 94( 656-690. Nku, N. (ed). (1982). Journey in Faith: The story of the Presbyterian Church in Cameroon. Buma Kor \& Co publishing house: Yoaunde.

[18] Nyakongo, H.O. (2015). Influence Of Motivation On Teachers' Job Performance In Public Secondary Schools In Rachuonyio South Sub - County, Homa-Bay County: Kenya

[19] PCC. (1957-2017). Daily Bible readings and Dairies. Printing Press: Limbe.

[20] PCC. (2015). Constitution (Revised edition). Pressprint: Limbe Pedler, M., Burgoyne, J. and Boydell, T. (1991). The Learning Company: A strategy for sustainable development, McGraw-Hill, Maidenhead

[21] 7 Petty, G. (2004). Teaching today: A practical guide (3 ${ }^{\text {rd }}$ ed). Nelson Thornes Ltd: Delta Place, UK.

[22] Purcell, J, Kinnie, K, Hutchinson, S, Rayton, B and Swart, J (2003). People and Performance: How people management impacts on organizational performance. CIPD: London

[23] Purcell, J., Kinnie, N., Hutchinson, s., Rayton, B. and Swart, J. (2003). Understanding the people and performance link: Unlocking the black box

[24] Shrestha, S. (2005). The role of human resource management on enhancing the teaching skills of Faculty members.

[25] Tambo.L.I. (2003). Cameroon National Education Policy Since the 1996 Forum. Design House: Limbe.

[26] Tsang, E. W. (1997). Organizational learning and the learning organization:

[27] a dichotomy between descriptive and prescriptive research. Human Relations, 50 (1), 73-89.

[28] Ulasi, N. A. (2011). Human resource management and productivity in Nigeria Public service. Enugu.

[29] Walton, J. (1999). Strategic Human Resource Development, Financial Times/Prentice Hall, Harlow. 